\title{
"Determinants of Islamic bank financing in the Middle East: Vector Error Correction Model (VECM)"
}

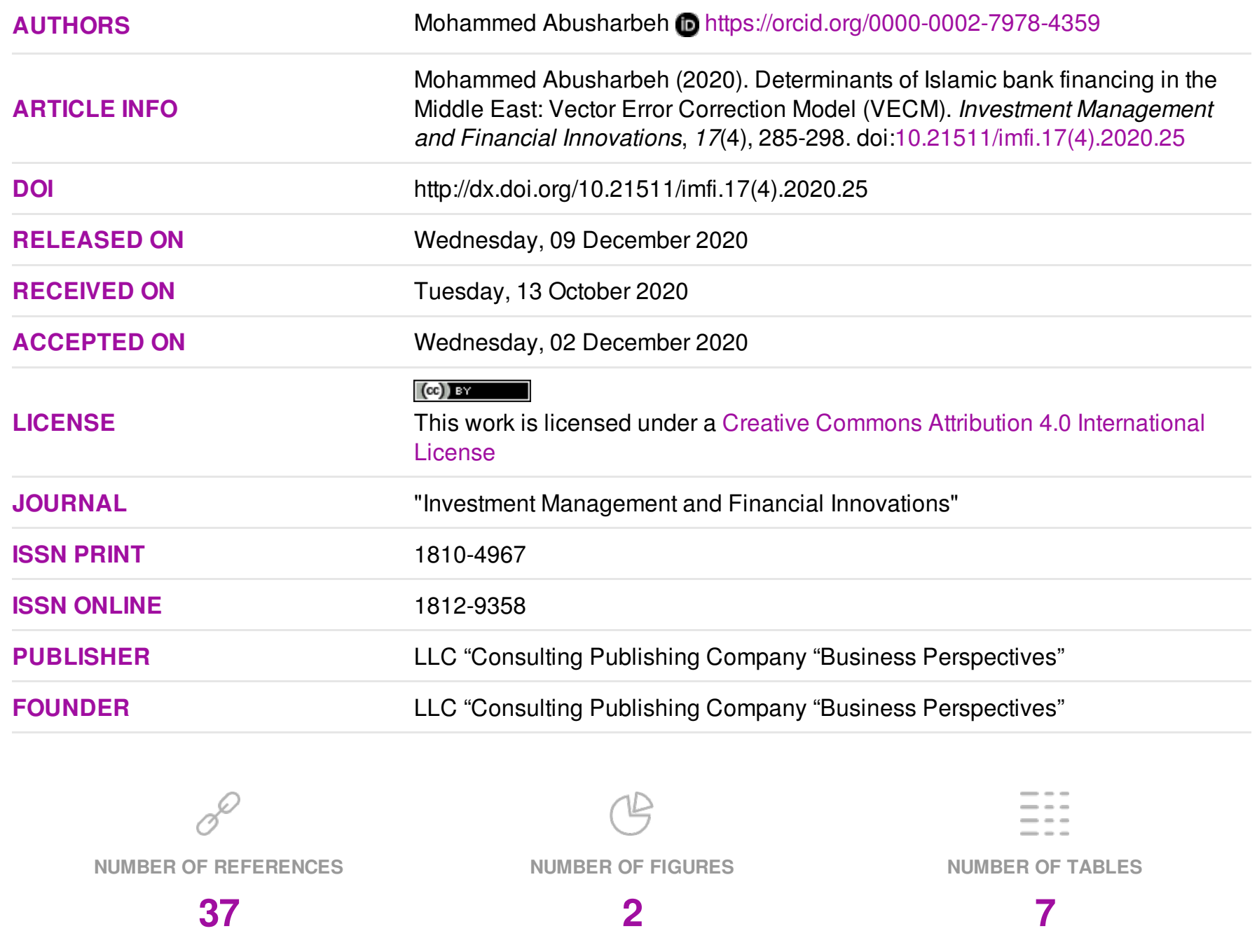

(c) The author(s) 2021. This publication is an open access article. 


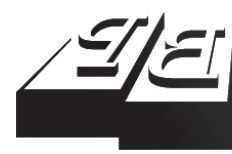

BUSINESS PERSPECTIVES

(O)

LLC "CPC "Business Perspectives"

Hryhorii Skovoroda lane, 10,

Sumy, 40022, Ukraine

www.businessperspectives.org

Received on: $13^{\text {th }}$ of October, 2020 Accepted on: $2^{\text {nd }}$ of December, 2020 Published on: $9^{\text {th }}$ of December, 2020

(c) Mohammed Abusharbeh, 2020

Mohammed Abusharbeh, Dr., Assistant Professor, Administrative and Financial Sciences Faculty, Finance Department, Arab American University, Palestine.

This is an Open Access article distributed under the terms of the Creative Commons Attribution 4.0 International license, which permits unrestricted re-use, distribution, and reproduction in any medium, provided the original work is properly cited.

Conflict of interest statement: Author(s) reported no conflict of interest

\section{DETERMINANTS OF ISLAMIC BANK FINANCING IN THE MIDDLE EAST: VECTOR ERROR CORRECTION MODEL (VECM)}

\begin{abstract}
As the world has been struck with a global financial crisis, Middle Eastern countries have been affected as well. Thus, Islamic banks have expanded, and the competitive advantage has become intensive with the increased number of conventional banks in the global banking system. This manuscript is aimed to examine the impact of macroeconomic and bank-specific factors on Islamic bank financing in the Middle Eastern countries. Therefore, the Vector Error Correction Model and the Granger causality test were run from 2009 to 2018 to detect the long- and short-run relationship between the explanatory variables and Islamic bank financing. The results suggest that both inflation and profitability negatively impact Islamic bank financing in the long run. The paper also revealed bidirectional causality between the variables GDP and bank size and Islamic bank financing. It shows that GDP and bank size are highly dominant factors of Islamic bank financing in the short run. Thus, this paper provides evidence that any short-run shock in the variables of GDP, inflation, and bank size will cause a long-term relationship with Islamic bank financing. This article's novelty is to ensure resilience within the Islamic banking system during and after the financial crisis. It provides evidence that Islamic banks can cushion their financial activities from economic volatility during the crisis. The results found can be used to predict the growth of Islamic bank financing in upcoming years in the Middle East and all emerging countries.
\end{abstract}

Keywords

Islamic finance, interest rate, inflation, profitability, cointegration, causality

JEL Classification E50, G21

\section{INTRODUCTION}

Islamic finance gained great attention after the 2008 global financial crisis. Its financial services have been growing faster globally in the last decade as the Islamic bank financing is growing not only in Arab and Islamic economies but also in various African and European economies. Citak and Hesse (2010) mentioned that Sharia-compliant financing and Islamic bank investments had been one of the fastest-growing sectors across 75 developed and developing countries. IFSB (2019) reported that Islamic banks' total assets are currently at USD 1.75 trillion and are expected to surpass USD 2.2 trillion in 2022. It is also expected that they will continue to grow within the coming years. This indicates that customers have sought alternative financial choices in funding their needs, depending not only on conventional banks but also on Islamic ones. Thus, Islamic banks comply with Islamic law and strive to increase their market share over their conventional counterparts (Kassim, 2016). Recently, Islamic banks had occupied more than twenty percent of the global banking system (IFSB, 2019). Moreover, Islamic banks achieved remarkable stability during the global financial crisis due to the realized assets compared with conventional loans (Selyowati, 2019). Indeed, this industry established a solid financing 
system, which has been more resilient to the global crisis and contributed significantly towards economic growth on a worldwide scale and in the Middle Eastern economies (Sakarya, 2016).

The adverse consequences of economic uncertainty tend to slow down Islamic bank financing. Furthermore, negative bank financial indicators could shrink the volume of Islamic bank financing (Shaikh, 2014). This paper aims to explain unexplored key drivers of Islamic bank financing and enrich existing prior works in different ways. First, this paper empirically examines the long-term and shortterm relationship between the explanatory variables (macroeconomic and bank-specific factors) and Islamic bank financing during the 2008 financial crisis. Thus, it employs a randomly selected annual dataset between 2009 and 2018 from some developing countries: Jordan, Palestine, Lebanon, Kuwait, and Qatar. Second, it aims to provide good knowledge in modeling factors of Islamic finance in emerging countries. This contribution increases the awareness of customers' behavior who may be concerned about macroeconomic and bank-specific factors when deciding their modes of financing, especially Murabaha contracts. To the best of our knowledge, no previous work has applied the vector error correction model in the area of Islamic finance and Middle Eastern countries. The novelty of this research is that the results found by using the VECM model can be used to predict the expected growth of Islamic bank financing in upcoming years, not only in the Middle East but also in all other emerging money markets.

\section{LITERATURE REVIEW AND HYPOTHESES}

\subsection{Islamic finance theory}

The topic of Islamic finance received attention from many academics and practitioners worldwide due to its resilience against the global financial crisis in 2008 (Hasan \& Dridi, 2010). Shahid and Abbas (2012) confirmed that the Islamic bank can adapt more efficiently than the conventional financial system during the global financial crisis. Similarly, Chakroun and Gallali (2015) stated that Islamic banks are less fragile than traditional banks as they were hit harder by the consequences of the financial crisis. Meanwhile, Cihák and Hesse (2010) argued that Islamic bank financing achieved better performance during the crisis than conventional financing as they had invested in real and liquid assets. This argument is supported by many scholars such as Bakri et al. (2017), Sakarya (2016), Rajhi and Hassairi (2013), and Kasri (2010).

From an Islamic perspective, profit-loss sharing (risk) is considered the foundation of Islamic financial transactions. Moreover, Islamic principles prohibit all financial investments that rely on interest (Riba), which is considered the root cause of the global financial crisis (Hasan \& Dridi, 2010). In this manner, Tariq and Masih (2016) stated that interest does not impact Islamic funding. Similarly, Mushtaq and Siddiqui (2017) found that Muslims who invest their money in Islamic banks tend to be indifferent about fluctuations in interest rates. Indeed, the absence of interest provides some confidence and trust between borrowers and creditors. Nevertheless, Abdul Kader and Leong (2009) and Ibrahim and Sufian (2014) found the interest rate to be the driving force behind Islamic banks' financial operations.

On the other hand, Islamic finance prohibits illegal activities such as gambling, gaharrar, mayser and speculations, and financing in pork or drugs (Mirakhor \& Iqbal, 2007). Thus, all financial transactions are bounded by Islamic principles and Sharia law. Hence, Islamic banks provide alternative modes of financing against interest-bearing loans, including; Murabaha contracts that allow the bank to buy an asset or commodity from a third party and later resell it again to another buyer at a price higher than the purchased price and then the bank got a markup (Moghul \& Ahmed, 2003). In the Ijara agreement, the sale of commodities is set at a specific time. In Ijara-based financing, the rental commission fees are paid to the buyer of goods, usually the bank (Selim, 2020). As for the Mudarabah contract, the bank provides the project's financing, and the other partner (speculator) manages the business through effort and time. While the bank incurs all losses 
in investment; however, when profit is retained, it is distributed between the two upon ratio agreed between the two parties (Ellahi et al., 2010). For the Musharakah agreement, the partners agree to contribute to capital based on profit and loss sharing. Thus, all parties are share risks and reward associated with it (Hanif \& Iqbal, 2010).

\subsection{Factors of Islamic bank financing}

Regarding the investigation of the determinants of Islamic bank financing, Cham (2018) analyzed Islamic bank financing factors in the MENA region in the years 2007-2010 using a generalized linear model. It was found that oil prices, domestic prices, and capital resources positively affect Islamic bank financing. Meanwhile, Naha and Sarker (2016) investigated the influence of various macroeconomic factors on Islamic bank financing in Muslim and non-Muslim countries between 2004 and 2013. Their findings indicated that the higher growth in GDP and inflation move Islamic bank financing forward. However, the exchange rate had a negative impact on Islamic bank financing of the selected countries.

In Pakistan, Nawaz (2019) investigated the factors that determine Islamic bank financing growth using structural equation modeling. It was found that the main determinants of banking growth are assets and equity. However, GDP has no significant impact on Islamic bank financing. Similarly, Zahid and Basit (2018) investigated the impact of GDP, inflation rate, money supply, total saving, and interest on Islamic banking growth in Pakistan from 1985 to 2015. They found that GDP and money supply had a positive effect on Islamic banks' growth, while interest rates, savings, and inflation rates were all found to be negatively correlated with Islamic banks' growth.

In Indonesia, Setyowati (2019) examined the factors that influence Islamic bank development. It was found that interest, exchange rates, and inflation have long-term asymmetric effects on Islamic bank financing, providing evidence that economic instability impacts Indonesian Islamic banks. Furthermore, Nursyamsiah (2017) examined the impact of real GDP, interest, and international trade on Islamic bank financing using a causality test and a vector autoregressive model. They found that
Islamic bank financing is sensitive to the declines in real output, interest, and international trade.

In Malaysia, Quan et al. (2019) examined the determinants of Islamic bank performance using ordinary least squares methods. They found that inflation is negatively correlated to Islamic bank performance. Furthermore, Bakri et al. (2017) examined the determinants of Islamic bank financing using linear and nonlinear vector autoregressive models. The results concluded that there was no asymmetric relationship between profit rate and Islamic bank financing. However, Ibrahim and Sufian (2014) evaluated the interrelation between key economic factors and Islamic bank financing using the structural VAR model. They found that Islamic bank financing responds positively to the change in GDP and is impacted negatively by the positive inflation and interest rate shock.

Given the limitations of prior works, this paper expands upon financial literature by adding new bank-specific factors, such as bank size and profitability, alongside macroeconomic factors to determine their effects on Islamic bank financing. To the best of the researcher's knowledge, this paper is considered the newest of its kind as it primarily explores the influence of Islamic bank financing determinants in some Middle Eastern countries using the Vector Error Correction Model (VECM).

\subsection{Research hypotheses}

Based on the debating of previous studies, this paper seeks to fill the research gap by examining the long-term and short-term impact of macroeconomic and bank-specific factors on Islamic bank financing in Middle Eastern countries. Therefore, this paper puts forward the following hypotheses:

$H_{1}: \quad$ There is a statistically significant long-term impact of the variables GDP, inflation, interest, bank size, and return on assets on Islamic bank financing in Middle Eastern countries from 2009 to 2018.

$\mathrm{H}_{2}$ : There is a statistically significant short-term impact of the variables GDP, inflation, interest, bank size, and return on assets on Islamic bank financing in Middle Eastern countries from 2009 to 2018. 
To confirm or reject the two hypotheses, this paper is conducted using some statistical methods as follows. First, unit root and Johansen's tests to check the stationery and long-term co-integration amongst research variables, respectively. Second, a residual test is used to check all VEC assumptions and the stability of the VEC model. Third, Vector Error Correction Model and Granger causality test are analyzed and presented to determine the long-term and shortterm relationships between the research variables and Islamic bank financing. Fourth, the impulse response function is used to test the dynamic short-run shock of Islamic bank financing in response to the change in macroeconomic and bank-specific factors.

\section{METHODS}

\subsection{Data collection and variables measurement}

As mentioned before, this article aims to examine the influence of the economic and bank-specific factors on Islamic bank financing in some Middle Eastern countries, including Jordan, Palestine, Lebanon, Kuwait, and Qatar. The data of Islamic bank financing (IF) were collected from the World Bank country database and each country's financial stability reports from 2009 to 2018. The following variables are used as independent variables: gross domestic product $(G D P)$, inflation $(I N F)$, interest on debt (I), bank size (SIZE), and profitability $(R O A)$. However, GDP and bank size are expressed in terms of the logarithm to unify the data variables. Thus, the definition of the research variables is shown in Table 1.

\subsection{Stationary test}

This paper assumes that all data variables involved are stationary to test con-integration between the research variables (GDP, I, INF, ROA, SIZE, and $I F)$. Thus, a unit root test is required to avoid spurious regression in data analysis, as mentioned by Gujarati (2004). Hence, this paper proceeds with stationarity for data series using ADF (Dickey \& Fuller, 1981) and PP (Phillips \& Perron, 1988) tests.

\subsection{Co-integration test}

After that, the paper tests the optimal lag criteria-based on Akaike Information Criterion (AIC) method to detect co-integration amongst the variables. All endogenous variables must be non-stationary in autoregressive distributed lag to use a co-integration test (Enders, 1995). Therefore, Johansen's co-integration test is used to determine the long-term relationship amongst the research variables, which the paper uses to tell the direction of causality between research variables (Johansen, 1988). Thus, the vector autoregressive model can be written as follows, as developed by Pesaran et al. (2001):

$$
\begin{aligned}
& \Delta I F_{t}=\beta_{0}+\sum_{k=1}^{n} \beta_{k} \Delta I F_{t-k}+ \\
& +\sum_{k=0}^{n} \delta_{k} \Delta x_{t-k}+\varphi_{1} I F_{t-1}+\varphi_{2} x_{t-1}+\mu_{t},
\end{aligned}
$$

\begin{tabular}{|c|c|c|c|}
\hline Group & Acronym & Definition & Empirical works \\
\hline \multirow[b]{3}{*}{$\begin{array}{l}\text { Economic } \\
\text { factors }\end{array}$} & GDP & $\begin{array}{l}\text { Gross domestic product (current USD) is annually measured for each } \\
\text { country (log of GDP) }\end{array}$ & Nawaz (2019), Cham (2018) \\
\hline & INF & $\begin{array}{l}\text { Inflation rate is measured by consumer price index (annual \%) for each } \\
\text { country }\end{array}$ & $\begin{array}{l}\text { Setyowati (2019), Ibrahim } \\
\quad \text { and Sufian (2014) }\end{array}$ \\
\hline & 1 & $\begin{array}{l}\text { Lending interest rate (\%) is defined as the bank rate that usually meets } \\
\text { the short- and medium-term loans. This rate is normally differentiated } \\
\text { according to the creditworthiness of borrowers. The terms and conditions } \\
\text { attached to these rates differ by country, however, limiting their } \\
\text { compatibility. Thus, conventional interest is measured in USD currency for } \\
\text { each country }\end{array}$ & $\begin{array}{c}\text { Nursyamsiah (2017), } \\
\text { Mushtaq and Siddiqui } \\
\text { (2017), Tariq and Masih } \\
\text { (2016) }\end{array}$ \\
\hline \multirow{2}{*}{ Bank-specific } & Size & $\begin{array}{l}\text { The bank size is calculated by total Islamic banks assets in each country (log } \\
\text { of annual total assets) }\end{array}$ & Haron (2004) \\
\hline & ROA & $\begin{array}{l}\text { The average return of assets for Islamic banks in each country is measured } \\
\text { by net income divided by total assets (annually) }\end{array}$ & Bakri et al. (2017) \\
\hline Dependent & IF & $\begin{array}{l}\text { The growth of Islamic bank financing in each country is measured by the } \\
\text { annual percentage change in financing (total Sharia-compliant financing } \\
\text { excluding interbank financing) to total assets }\end{array}$ & $\begin{array}{l}\text { Nursyamsiah (2017), } \\
\text { Adebola et al. (2011) }\end{array}$ \\
\hline
\end{tabular}

Table 1. Variables definition and previous works used 
where $\Delta I F_{t}$ is the change in the dependent variable (Islamic bank financing), $\beta_{0}$ denotes an intercept, $x_{t-k}$ refers to the vector of regressors, $\varphi_{1}$ and $\varphi_{2}$ denote the speed of adjustment in which $I F_{t}$ returns to long term equilibrium due to change in $x$. $\beta_{k}$ and $\delta_{k}$ refer to the short-term coefficients of relationships, $k=1$ indicates the optimal lag order of the research variables, and indicates the $_{t}$ disturbance term.

\subsection{VECM, causality, and impulse response function}

In this case, if the data variables are nonstationary, then the study utilizes ARDL to detect longterm dynamics of series between IF and the explanatory variables (Granger \& Engle, 1987). Thus, the paper replaces the long term ARDL components $\left(\varphi_{1} y_{t-1}+\varphi_{2} x_{t-1}\right)$ with $\varphi z_{t-1}$ or $E C T_{t-1}$ to adjust the speed of long-term equilibrium. $Z_{t-1}$ measures the OLS residuals from long-term co-integration regression. Hence, the traditional Error Correction Model (ECM) for co-integrated series is expressed by the following equation:

$$
\begin{aligned}
& \Delta I F_{t}=\beta_{0}+\sum_{k=1}^{n} \beta_{k} \Delta I F_{t-k}+ \\
& +\sum_{k=0}^{n} \delta_{k} \Delta x_{t-k}+\varphi z_{t-1}+\mu_{t} .
\end{aligned}
$$

In the context of VECM, further analysis should be used to evaluate the economic policy in the selected countries. The Granger causality test can be used to check whether the variables' time series is useful in predicting each other (Granger, 1969). However, suppose the Granger causality test does not completely interpret the interaction between explanatory variables. In that case, the impulse response function can be used to understand the short-run shock for the dynamic system in response to the changes in some external factors.

\section{EMPIRICAL RESULTS}

\subsection{Descriptive analysis}

Table 2 exhibits the descriptive statistics of the mean and standard deviation (in first-order lag). The results show that Islamic bank financing across Palestine, Jordan, Lebanon, Kuwait, and
Qatar recorded positive average changes of 7.1\% per year, while the mean values of GDP and bank size saw positive changes at $6 \%$ and $3.9 \%$, respectively. However, the remaining variables inflation, interest rate, and ROA displayed negative average yearly changes at $-52.3 \%,-2 \%$, and $-7.2 \%$. This indicates that negative growth was recorded in economic factors throughout the study due to the impact of the global crisis between 2009 and 2018. In terms of standard deviation, Islamic bank financing had shown slight volatility throughout the study at $6.9 \%$.

\begin{tabular}{|c|c|c|c|c|c|c|}
\hline & $\Delta I F$ & $\triangle G D P$ & $\Delta I N F$ & $\Delta I$ & $\triangle S I Z E$ & $\triangle R O A$ \\
\hline Mean & 0.071 & 0.060 & -0.523 & -0.020 & 0.039 & -0.072 \\
\hline St. deviation & 0.069 & 0.122 & 1.840 & 0.0813 & 0.0648 & 1.106 \\
\hline Skewness & 0.848 & -0.607 & -1.776 & -0.1808 & 0.631 & -4.569 \\
\hline Kurtosis & 3.349 & 4.998 & 8.908 & 3.569 & 4.770 & 29.993 \\
\hline Jarque-Bera & 6.246 & 11.398 & 99.013 & 0.942 & 9.855 & 1692 \\
\hline$p$-value & 0.044 & 0.003 & 0.000 & 0.624 & 0.007 & 0.000 \\
\hline Observation & 50 & 50 & 50 & 50 & 50 & 50 \\
\hline
\end{tabular}

Table 2. Descriptive statistics

Note: Observation value equals the five countries multiplied by 10 years (2009-2018).

\subsection{Unit root test}

Table 3 shows the unit root test results, including intercepts and trends, to detect stationarity amongst Islamic bank financing and the explanatory variables (Dickey \& Fuller, 1981). The ADF and $\mathrm{PP}$ tests results provide evidence that the variables are stationarity at the level $I(0)$ except the variable SIZE. Therefore, $t$-values of ADF and PP are less than the critical value and significant at the level of $1 \%$ in $I(0)$, except SIZE integrated at first difference $I(1)$. Therefore, it is appropriate to build up the VECM model in the first difference of the variables $I(1)$.

\begin{tabular}{|c|c|c|c|c|}
\hline \multirow[t]{2}{*}{ Series } & \multicolumn{2}{|c|}{$\begin{array}{l}\text { Augmented } \\
\text { Dickey-Fuller }\end{array}$} & \multicolumn{2}{|c|}{ Philips-Perron } \\
\hline & At level & $1^{\text {st }}$ order & At level & $1^{\text {st }}$ order \\
\hline $\mathrm{D}\{I F(-1)\}$ & $-5.13^{*}$ & $-4.19 *$ & $-5.10 *$ & $-35.6 *$ \\
\hline$D\{G D P(-1)\}$ & $-5.62 *$ & $-4.10^{*}$ & $4.16^{*}$ & $-13.8^{*}$ \\
\hline $\mathrm{D}\{I N F(-1)\}$ & $-6.76^{*}$ & $-8.06^{*}$ & $-6.76^{*}$ & $-17.3^{*}$ \\
\hline $\mathrm{D}\{I N T(-1)\}$ & $-4.73^{*}$ & $-4.43^{*}$ & $6.35^{*}$ & $-28.9 *$ \\
\hline$D\{S I Z E(-1)\}$ & -1.67 & $-7.73^{*}$ & -4.04 & $-16.4^{*}$ \\
\hline $\mathrm{D}\{R O A(-1)\}$ & $5.68 *$ & $-7.71^{*}$ & $-5.67^{*}$ & $-34.3^{*}$ \\
\hline
\end{tabular}

Table 3. The results of unit root test

Note: ${ }^{*}$ denotes significance at $1 \%$ level. 
The next step is to select the optimal number of lags for the estimated model. It depends on the lowest value of the Akaike Information Criterion (AIC) as the primary selection method. The result indicated that the optimal lag for all variables is number four at a $1 \%$ level of significance as estimated by EViews. Thus, one proceeds with further tests at lag (4) with a minimum AIC of -2.2479 .

\subsection{Co-integration analysis}

Table 4 illustrates the results of the Johansen co-integration test. The result indicates that trace values are greater than critical values amongst the series; IF, GDP, INF, INT, SIZE, and ROA. Thus, the test result rejects the null hypothesis $\left(H_{0}: r=0\right)$ under the $5 \%$ level, and three positive relationships exist. The result provides evidence of 4 co-integrating equations amongst the endogenous variables at the 5\% level. The result indicated that the selected series are stable with long-term equilibrium. Thus, VECM is more appropriate in conducting research findings.
Table 4. The results of the co-integration rank test (Trace)

\begin{tabular}{|c|c|c|c|c|}
\hline \multicolumn{3}{|c|}{ Trend: Linear deterministic trend } & \multicolumn{2}{|c|}{$\begin{array}{c}\text { Lag interval } \\
\text { (at first } \\
\text { differences): } 1 \text { to } 4\end{array}$} \\
\hline $\begin{array}{c}\text { Co-integration } \\
\text { eq. No. }\end{array}$ & Eigenvalue & $\begin{array}{c}\text { Trace } \\
\text { statistics }\end{array}$ & $\begin{array}{c}\text { Critical } \\
\text { value }\end{array}$ & $p$-value \\
\hline None* & 0.816545 & 202.8082 & 95.75366 & 0.0000 \\
\hline At most $1^{*}$ & 0.791836 & 126.4978 & 69.81889 & 0.0000 \\
\hline At most $2^{*}$ & 0.435575 & 55.87352 & 47.85613 & 0.0047 \\
\hline At most $3^{*}$ & 0.305491 & 30.13590 & 29.79707 & 0.0457 \\
\hline
\end{tabular}

Note: Trace value denotes 1 co-integration equation at 5\% level of significance.

The results of error correction $\left(E C T_{t-1}\right)$ at first co-integration order provides a co-integration equation between the variables $I F, G D P$, inflation, interest, bank size, and return on assets as shown in equation (3) (long-run model):

$$
\begin{gathered}
E C T_{t-1}=1.000(I F)-0.813(G D P)- \\
-0.043(I N F)-0.466(I N T)- \\
(0.009) \\
-1.523(S I Z E)-0.0369\left(\text { ROA }_{(0.013)}\right)+0.004 .
\end{gathered}
$$

Source: Author's estimation.

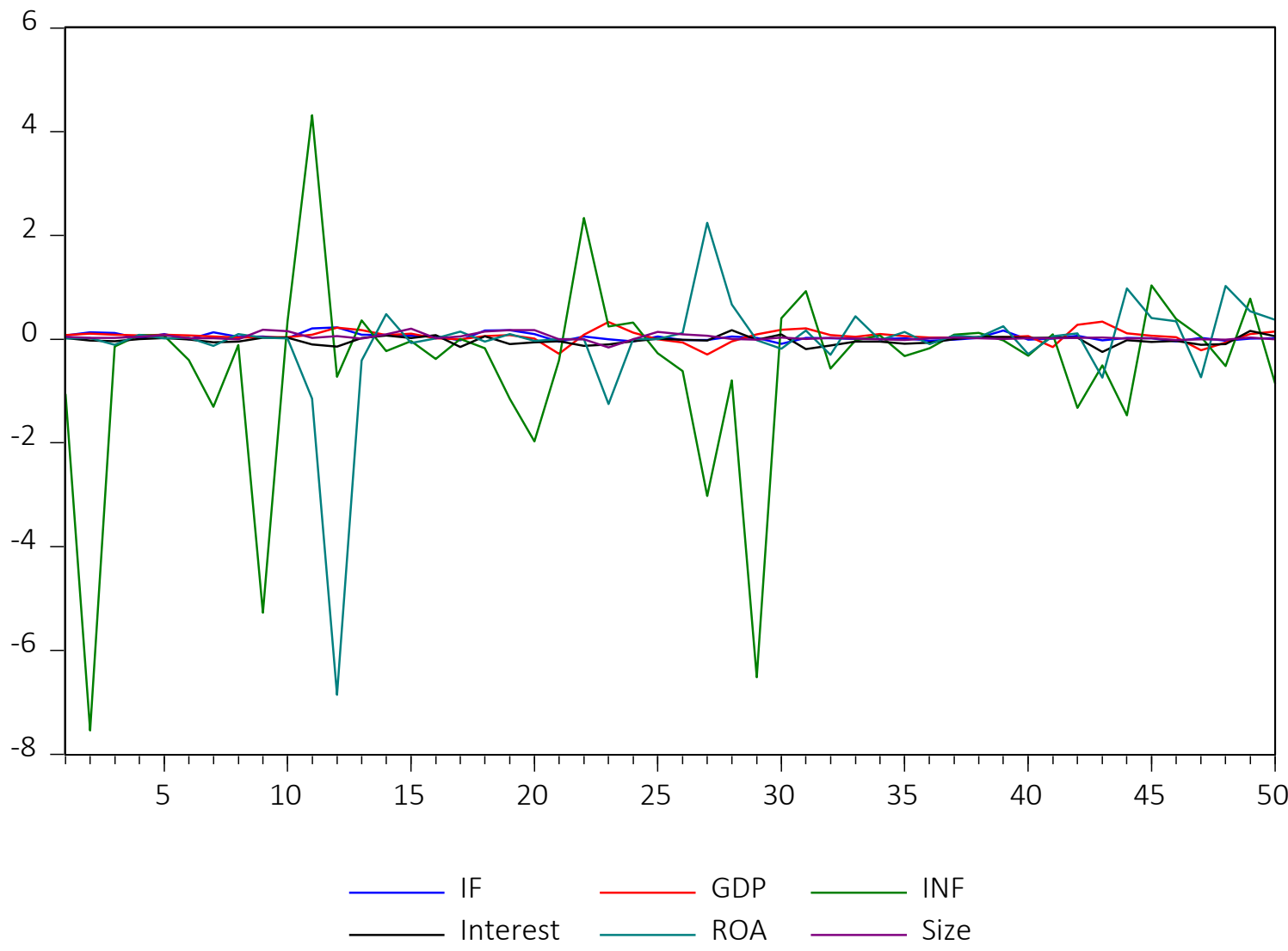

Figure 1. Co-integration relationships 
Table 5. VEC residual tests

\begin{tabular}{|c|c|c|c|c|}
\hline Residual test & Statistical approach & Chi-squared & Prob. & Decision \\
\hline \multirow{3}{*}{ Normality (joint) } & Skewness & 3.950205 & 0.6834 & \multirow{3}{*}{ Normal } \\
\hline & Kurtosis & 1.647960 & 0.9491 & \\
\hline & Jarque-Bera & 5.598165 & 0.9350 & \\
\hline Autocorrelation & \multirow{4}{*}{ LM test } & Rao F-stat & Prob. & \multirow{4}{*}{ No serial correlation } \\
\hline Lag 1 & & 1.293565 & 0.1785 & \\
\hline $\operatorname{Lag} 2$ & & 0.928031 & 0.5886 & \\
\hline $\operatorname{Lag} 3$ & & 0.800173 & 0.7650 & \\
\hline \multirow{2}{*}{ Heteroscedasticity } & \multirow{2}{*}{ Joint test } & Chi-squared & Prob. & \multirow{2}{*}{ Homoscedastic } \\
\hline & & 818.4130 & 0.3004 & \\
\hline
\end{tabular}

Based on the co-integration equation (3), it can be indicated that only inflation and return on assets have a long-term relationship with Islamic bank financing. This means that each percentage increase in inflation will decrease Islamic bank financing by $4.3 \%$, and this estimate was significant at the $5 \%$ level. Similarly, one percent appreciation in Islamic banks' profit is likely to reduce Islamic bank financing by $3.69 \%$. Moreover, Figure 1 presents the stability line and long-term relationship equilibrium among the endogenous variables. It can be seen that there is a large fluctuation in the inflation rate and profitability of Islamic banks across the Middle Eastern countries over the 10 years due to the impact of the 2008 global financial crisis. This implies that short-term variability in this period significantly deviated from the long-term relationship. Nevertheless, Islamic bank financing is steadily stable despite the financial and political crises.

Table 5 shows the validity of VECM; residual test series should be normally distributed, with no serial correlation, and homoscedastic. This paper uses the VEC residual normality test to check the normality of the dataset. The result indicates the series is jointly followed a normal distribution and the $p$-value of Jarque-Bera $(0.9350)$ is greater than the $5 \%$ significance level. Furthermore, this paper uses Lagrange Multiplier (LM) test to check the serial autocorrelation among endogenous variables. The result of LM test reveals no autocorrelation at lag $h$. This proves the absence of autocorrelation up to lag 3. In case of heteroscedasticity, this paper applies white VEC residuals heteroscedasticity test. The result concludes that the series are ho- moscedastic with a high Chi-squared value of 818.4 and $p$-value of 0.3004 above the $5 \%$ level. Thus, VECM is stable and valid to use in testing the research hypotheses.

\subsection{The results of VECM}

This model is used to detect the presence of the long-term relationships between the endogenous variables. Consequently, the VAR model can be estimated at first-order $I(1)$, including the error correction term $\left(E C T_{t-1}\right)$ with the same optimal $\operatorname{lag}(k)$ minus $1(K-1=3)$ to estimate the Vector Error Correction Model (VECM).

Table 6 exhibits that the powers of determination are greater than $0.5\left(R^{2}<0.5\right)$, and that the likelihood is large (157.1329) and AIC is relatively small (-1.353606), which implies well-fitting VECM estimation. Thus, this supports alternative Hypothesis $1\left(H_{1}\right)$, indicating that inflation and profitability have long-term equilibrium with Islamic bank financing in three co-integrating equations. The results provide evidence that inflation has a negative correct sign with Islamic bank financing. Thus, the decline in Islamic bank financing is related to the increase in the inflation rate. However, profitability (ROA) has the same negative sign after correction. It is commonly believed that an economy with a low inflation rate exhibits growth in Islamic bank financing as credit facilities' prices increase in conventional counterparts. This action attracts more deposits to Islamic banks and enables more customers to obtain funds in different Islamic bank financing ways. Nevertheless, higher ROA tends to decline the demand for Islamic bank growth. Thus, ECM can be written, as shown in equation (4): 
Table 6. Results of VECM estimates

Source: Author's estimation.

\begin{tabular}{|c|c|c|c|c|c|c|}
\hline Error correction & $\mathrm{D}(I F)$ & $\mathrm{D}(G D P)$ & $\mathrm{D}(I N F)$ & $\mathbf{D}(I N T)$ & $\mathrm{D}(S I Z E)$ & $\mathrm{D}(R O A)$ \\
\hline CointEq1 & -0.052702 & 0.904432 & -6.441145 & -0.030502 & 2.065531 & 0.218931 \\
\hline $\mathrm{D}(I F(-1))$ & -0.538502 & -0.486061 & -6.469055 & 0.075744 & -7.290897 & -0.070039 \\
\hline $\mathrm{D}(I F(-2))$ & -0.413025 & -1.263063 & -13.71218 & 0.563873 & -2.531979 & 0.220413 \\
\hline $\mathrm{D}(I F(-3))$ & -0.793002 & -0.908207 & -3.997302 & 0.208975 & -0.533775 & -0.435760 \\
\hline$D(G D P(-1))$ & -0.287463 & 0.103084 & -0.833455 & -0.275259 & 0.080684 & -0.110635 \\
\hline $\mathrm{D}(G D P(-2))$ & 0.095817 & -0.051926 & 0.221303 & -0.093989 & 0.118030 & 0.239231 \\
\hline$D(G D P(-3))$ & -0.257118 & -0.203901 & 3.011519 & -0.256753 & -0.774626 & $-0.043948^{* *}$ \\
\hline $\mathrm{D}(I N F(-1))$ & $-0.018238^{* *}$ & $0.009313^{* *}$ & -0.892102 & $-0.003315^{* *}$ & -0.210904 & $0.001498^{* *}$ \\
\hline $\mathrm{D}(I N F(-2))$ & $-0.003127 * *$ & $-0.021099 * *$ & -0.412734 & $0.008324 * *$ & -0.057689 & $0.002449 * *$ \\
\hline $\mathrm{D}(\operatorname{INF}(-3))$ & $-0.016224^{* *}$ & $-0.018796 * *$ & -0.161104 & $0.004163^{* *}$ & 0.161522 & -0.010903 \\
\hline $\mathrm{D}(I N T(-1))$ & 0.239222 & -0.560148 & 5.544194 & -0.631144 & -3.162169 & -0.007944 \\
\hline $\mathrm{D}(I N T(-2))$ & -0.095206 & -0.770204 & 7.393485 & -0.369487 & -3.693103 & -0.120839 \\
\hline $\mathrm{D}(I N T(-3))$ & -0.057068 & -0.677489 & 3.895044 & -0.225528 & -2.987197 & -0.117077 \\
\hline $\mathrm{D}(S I Z E(-1))$ & 0.536745 & 1.071253 & -7.696275 & 0.320367 & 5.478933 & 0.218657 \\
\hline $\mathrm{D}(S I Z E(-2))$ & -0.245659 & 0.178366 & 1.089315 & -0.564264 & 5.223341 & -0.303299 \\
\hline $\mathrm{D}(S I Z E(-3))$ & 0.334186 & 0.642632 & 1.450627 & -0.279844 & -2.631669 & -0.088315 \\
\hline $\mathrm{D}(R O A(-1))$ & $-0.011373 * *$ & $0.012686^{* *}$ & -0.878319 & $0.033422 * *$ & -0.469426 & $0.026577^{* *}$ \\
\hline $\mathrm{D}(R O A(-2))$ & $-0.037193^{* *}$ & $-0.010434 * *$ & -0.896628 & $0.016481^{* *}$ & -0.141520 & $-0.000463^{* *}$ \\
\hline $\mathrm{D}(R O A(-3))$ & $-0.011582^{* *}$ & $0.008637^{* *}$ & -0.360573 & $0.009715^{* *}$ & -0.209570 & $-0.011827 * *$ \\
\hline C & $-0.004870^{* *}$ & $-0.002942^{* *}$ & 0.043238 & $0.000495^{* *}$ & -0.011191 & $-0.001688^{* *}$ \\
\hline$R$-squared & 0.663441 & 0.716491 & 0.540119 & 0.683099 & 0.707234 & 0.687432 \\
\hline Log likelihood & \multicolumn{6}{|c|}{157.1329} \\
\hline AIC & \multicolumn{6}{|c|}{-1.353606} \\
\hline
\end{tabular}

Note: $* *$ denotes the significance level at $5 \%$.

$$
\begin{aligned}
& \left(\begin{array}{c}
\Delta(I F) \\
\Delta(G D P) \\
\Delta(I N F) \\
\Delta(I N T) \\
\Delta(S I Z E) \\
\Delta(R O A)
\end{array}\right)=\left(\begin{array}{c}
-0.005 \\
-0.003 \\
0.043 \\
0.001 \\
-0.011 \\
-0.002
\end{array}\right)+\left(\begin{array}{cccccc}
-0.54 & -0.49 & -6.47 & -0.08 & -7.29 & -0.07 \\
-0.29 & 0.10 & -0.83 & -0.28 & 0.08 & -0.11 \\
0.02 & 0.01 & -0.89 & -0.00 & -0.21 & 0.00 \\
0.24 & -0.56 & 5.54 & -0.63 & -3.12 & -0.00 \\
0.54 & 1.07 & -7.69 & 0.32 & 5.47 & 0.22 \\
-0.01 & 0.01 & -0.88 & 0.03 & -0.47 & 0.03
\end{array}\right)\left(\begin{array}{c}
\Delta\left(I F_{k-1}\right) \\
\Delta\left(G D P_{k-1}\right) \\
\Delta\left(I N F_{k-1}\right) \\
\Delta\left(I N T_{k-1}\right) \\
\Delta\left(S I Z E_{k-1}\right) \\
\Delta\left(R O A_{k-1}\right)
\end{array}\right)+ \\
& +\left(\begin{array}{cccccc}
-0.41 & -1.26 & -13.7 & 0.56 & -2.53 & 0.22 \\
0.10 & -0.05 & 0.22 & -0.09 & 0.12 & 0.24 \\
-0.00 & -0.02 & -0.41 & 0.01 & -0.06 & 0.00 \\
-0.10 & -0.77 & 7.39 & -0.37 & -3.69 & -0.12 \\
-0.24 & 10.8 & 1.09 & -0.56 & 5.22 & -0.30 \\
-0.03 & 0.01 & -0.89 & 0.02 & -0.14 & -0.00
\end{array}\right)\left(\begin{array}{c}
\Delta\left(I F_{k-2}\right) \\
\Delta\left(G D P_{k-2}\right) \\
\Delta\left(I N F_{k-2}\right) \\
\Delta\left(I N T_{k-2}\right) \\
\Delta\left(S I Z E_{k-2}\right) \\
\Delta\left(R O A_{k-2}\right)
\end{array}\right)+ \\
& +\left(\begin{array}{cccccc}
-0.79 & -0.91 & -3.99 & 0.21 & -0.53 & -0.43 \\
-0.26 & -0.20 & 3.01 & -0.26 & -0.77 & -0.04 \\
-0.02 & -0.02 & -0.16 & 0.00 & 0.16 & -0.01 \\
-0.06 & -0.67 & 3.89 & -0.22 & -2.89 & -0.12 \\
0.33 & 0.64 & 1.45 & -0.28 & -2.63 & -0.09 \\
-0.01 & 0.01 & -0.36 & 0.01 & -0.21 & -0.01
\end{array}\right)\left(\begin{array}{c}
\Delta\left(I F_{k-3}\right) \\
\Delta\left(G D P_{k-3}\right) \\
\Delta\left(I N F_{k-3}\right) \\
\Delta\left(I N T_{k-3}\right) \\
\Delta\left(S I Z E_{k-3}\right) \\
\Delta\left(R O A_{k-3}\right)
\end{array}\right)
\end{aligned}
$$




\subsection{Granger causality analysis}

The co-integration equation indicates long-term relationships between three variables, namely $I F$, $I N F$, and ROA. However, in terms of short-term relationships, further causality testing is required. The Granger causality analysis is used to detect if the endogenous variables help predict a dependent variable based on the past values and endogenous variables (Granger \& Yoon, 2002).

Table 7 shows the Granger causality test's findings to detect the short-run relationship between IF and other endogenous variables. The results show that bidirectional causality between the variables GDP, bank size, and IF. Therefore, this supports Hypothesis $2\left(\mathrm{H}_{2}\right)$. Indeed, higher GDP and large banks move Islamic bank financing forward and boost Islamic banks to provide more funds to their customers. This argument is consistent with Setyowati (2019) and Bakri et al. (2017). The result also shows that higher inflation rates could cause growth in Islamic bank financing, indicating unidirectional causality with Islamic bank financing, which is in line with Setyowati's (2019) results who mentioned that CPI does ganger cause Islamic bank financing in Indonesia. However, the other variables, such as interest and return on assets, did not cause Islamic bank financing changes. This means that a higher interest rate and Islamic profit rate do not intend to change the Islamic bank financing in the short run. This means that Islamic banks' customers will not compare the conventional interest rate with the profit margin in the Islamic banking system when they obtain funds.

\subsection{Impulse response function}

Figure 2 presents the impulse response function for the research variables following in response to Cholesky's one standard deviation to further analyze the dynamic impact of VECM responding to certain shocks of economic crises and the variables themselves. The results show that Islamic bank financing positively responds to the shock itself during the last 10 years. Moreover, Islamic bank financing positively responds to the changes in the variables of GDP, interest, and bank size in the short run. However, financing responds negatively to the variation in both inflation and ROA in the third year of the study and gets stable over the rest of the period.

\section{DISCUSSION}

This research has modeled the long-term and short-term relationship between GDP, inflation, interest, size, profitability, and Islamic bank financing in the Middle Eastern countries of Jordan, Palestine, Lebanon, Kuwait, and Qatar. Therefore, the researcher used ADF and PP tests to detect the stationary amongst the research variables. The results indicated that $t$-values of all research variables are stationary at the first difference $I(1)$. It was concluded that VECM is appropriate for estimating long-term co-integration amongst the research variables.

The next step is to eliminate the autocorrelation case in the VAR model by determining the optimal lag length. Using the smallest value of the

Table 7. The results of block exogeneity Wald test (short-run)

\begin{tabular}{|c|c|c|c|c|c|}
\hline Null hypothesis & Chi-squared & $p$-value & Granger status & Direction & Conclusion \\
\hline GDP does not Granger cause (IF) & 10.775 & 0.0130 & Yes & \multirow{2}{*}{ Bidirectional } & Reject \\
\hline IF does not Granger cause (GDP) & 16.756 & 0.0008 & Yes & & Reject \\
\hline INF does not Granger cause (IF) & 18.054 & 0.0004 & Yes & \multirow{2}{*}{ Unidirectional } & Reject \\
\hline IF does not Granger cause (INF) & 5.144 & 0.1615 & No & & Accept \\
\hline INT does not Granger cause (IF) & 5.136 & 0.1623 & No & \multirow{2}{*}{ Non } & Accept \\
\hline IF does not Granger cause (INT) & 6.043 & 0.1095 & No & & Accept \\
\hline ROA does not Granger cause (IF) & 8.875 & 0.0760 & No & \multirow{2}{*}{ Non } & Accept \\
\hline IF does not Granger cause $(R O A)$ & 6.740 & 0.0806 & No & & Accept \\
\hline SIZE does not Granger cause (IF) & 9.719 & 0.0021 & Yes & \multirow{2}{*}{ Bidirectional } & Reject \\
\hline IF does not Granger cause (SIZE) & 15.321 & 0.0002 & Yes & & Reject \\
\hline
\end{tabular}


Response to Cholesky One S.D. (d.f. adjusted) Innovations \pm 2 S.E.

Response of IF to IF

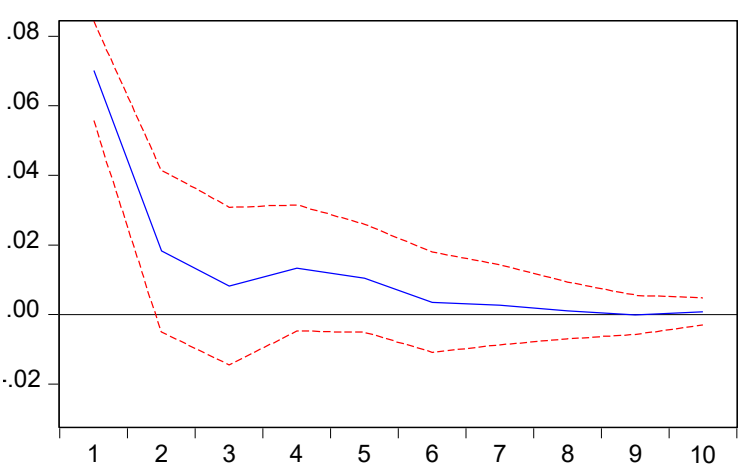

Response of IF to INF

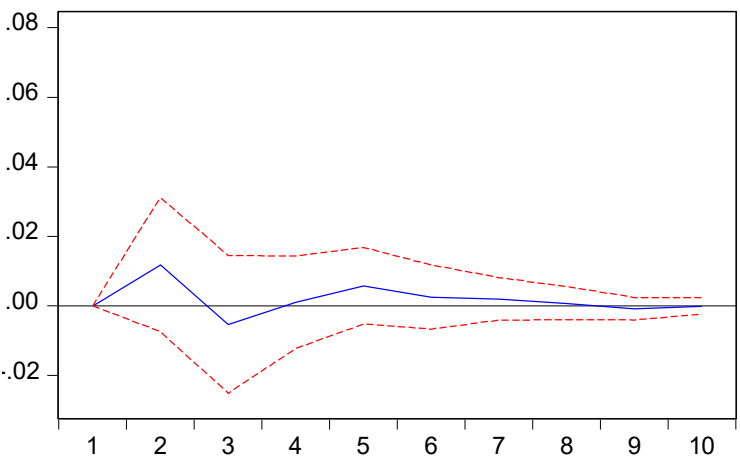

Response of IF to ROA

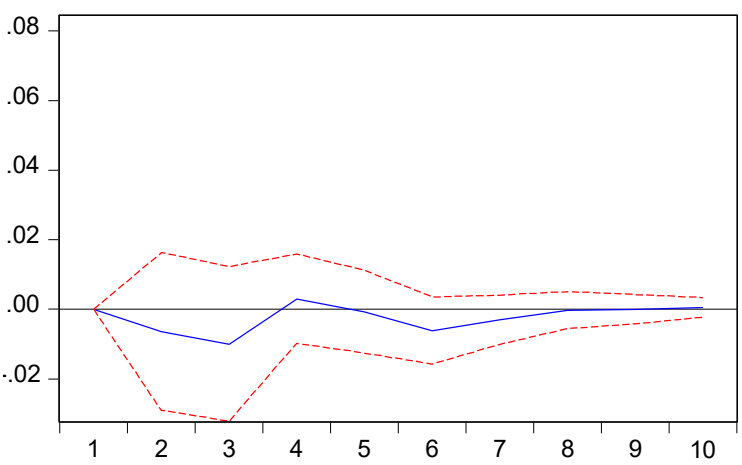

Response of IF to GDP
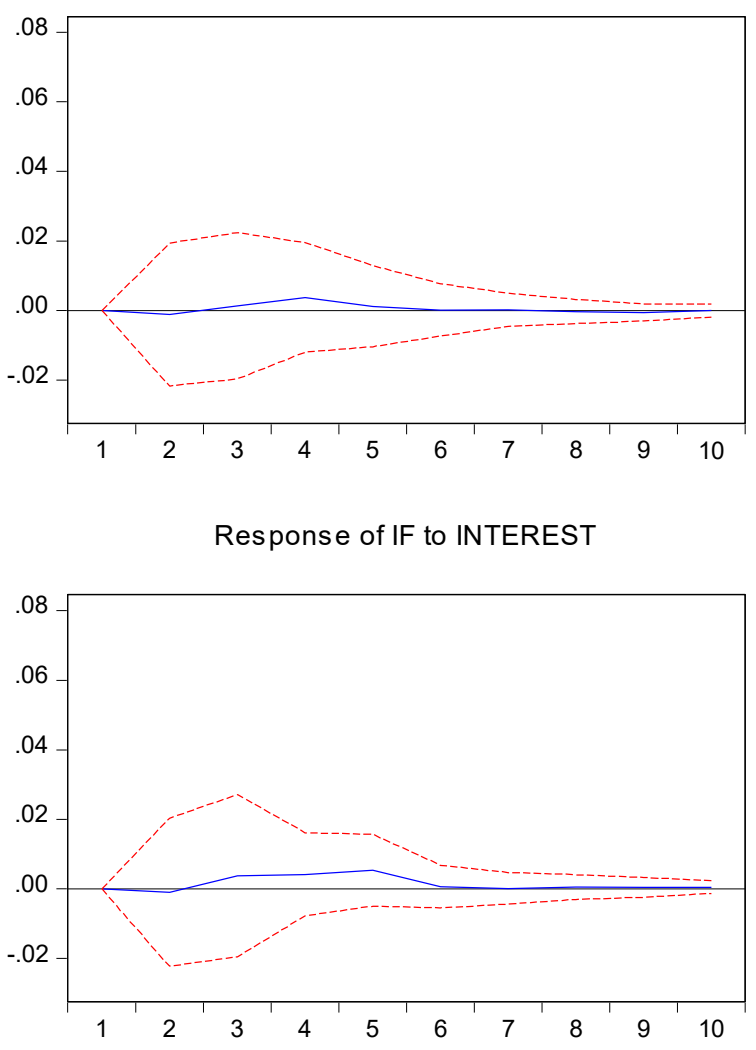

Response of IF to SIZE

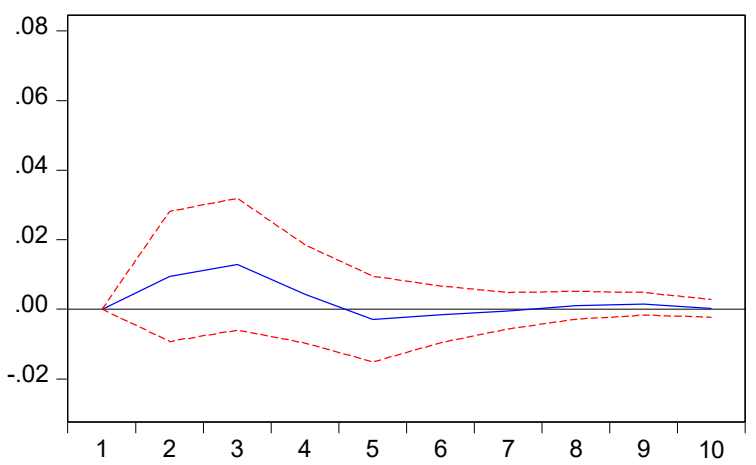

Figure 2. Dynamic responses of financing to the explanatory variables

Akaike Information Criterion (AIC), it can be concluded that the optimal lag number is 4 . This indicates that all the variables are affected by each other in the current period and previous periods. After that, this paper used the Johansen co-integration test to see the existence of a long-term relationship amongst the variables in the model.

The result of VECM provides evidence that the growth of Islamic bank financing is not affected by the fluctuation of the business cycle that reflects the variability of GDP. This argument is contrary to that of Nursyamsiah (2017) and Ibrahim and Sufian (2014); however, it is consistent with the findings of Nawaz (2019). Moreover, interest was found to have no impact on Islamic bank financing, indicating that interest is prohibited given Islamic bank ideology. Therefore, the conventional interest rate change will not lead to a change in Islamic banks' growth. This result is consistent 
with Tariq and Masih (2016) and Mushtaq and Siddiqui (2017). The inflation rate as a measure of the price level was shown to have a significant negative impact on Islamic bank financing in the long run, which means when there is an increase in consumer price index by $4.3 \%$, there will be a decrease of $1 \%$ in Islamic bank financing. This indicates the continuous increase in prices of goods and services, which leads to a decline in the supply of funding in Islamic banks. This result is consistent with Setyowati (2019) and Ibrahim and Sufian (2014) findings.

As for long-run bank-specific factors, the result shows that bank size has a limited predictor of Islamic bank financing. This indicates that different sizes of Islamic banks in Middle Eastern counties are not essential in predicting Islamic finance growth. Therefore, the current study provides new evidence in modeling Islamic bank financing, indicating that large bank size is not considered a crucial factor of Islamic bank financing. This result conflicts with Haron (2004) who argued that bank size positively affects bank growth. However, ROA has a negative long-term association with Islamic bank financing in Middle Eastern countries, which means that a $1 \%$ increase in ROA reduces Islamic banking's capacity to provide funds by $3.69 \%$. This provides evidence that lower profitable Islamic banks tend to increase the level of their financing.

In the case of a short-term relationship, the current study shows a bidirectional causality between GDP and Islamic bank financing, indicating that Islamic bank financing will rise when there is an increase in GDP and vice versa. This result accelerates the business process and boosts Islamic banks toward funding production to attain more profits. On the other hand, the Granger causality test result shows that inflation and Islamic bank financing have unidirectional causality. This means that customers purchasing consumption goods through a Murabaha contract tend to increase the demand and prices of purchasing items, which causes higher inflation (Setyowati, 2019). However, inflation does not Granger cause growth in Islamic bank financing.

The current study found no causality between the interest rate and financing (IF), which indicates that Islamic banks prohibit interest rates from being gained and paid in their financial activities. This argument is in line with the findings of Kassim et al. (2009) and Tariq and Masih (2016). The results also show no casualty between profitability and Islamic bank financing in the short run. A variation in ROA would not have any effect on Islamic bank financing. Nevertheless, the results show bidirectional causality between bank size and Islamic bank financing, showing the higher value of assets leads to move Islamic bank financing forward and vice versa. This result pushes Islamic banks toward expansion and raising their capital to invest in real assets and gain more profits.

Finally, the impulse function results indicate that Islamic bank financing reacts positively to itself during all periods of the study (2009-2018) despite the crisis and political instability in the Middle East. It provides evidence that Islamic banks can cushion their financial stability and foster financing growth (Hasan \& Dridi, 2010). Islamic bank financing shows a positive response to changes in GDP, where this response gets stable during all the periods; this result is confirmed by the Granger causality between GDP and Islamic bank financing. Similarly, the results indicate a positive response of Islamic bank financing towards the variability of interest rate as this response was stable over the last 10 years (2009-2018). This result clearly explains how Islamic banks protect themselves from the financial crisis (Bakri et al., 2017). Moreover, Islamic bank financing responds negatively to the shock in inflation and ROA. These responses have high volatility in the third year for both inflation and profitability factors. The changes in bank size cause positive responses in the first two periods of study. After that, it remains stable over the rest of the period. This indicates that a large bank size moves Islamic bank financing forward in the short run. 


\section{CONCLUSION}

This article aimed to examine the influence of macroeconomics, such as GDP, Inflation, and interest, and bank-specific factors, the ROA and size, on Islamic bank financing in Middle Eastern countries. Based on VECM, the result supports Hypothesis 1, indicating the existence of a long-term relationship between the variables inflation and ROA and Islamic bank financing. Inflation and ROA are shown to have a negative impact on Islamic bank financing. Furthermore, the Granger causality test of VEC found that any short-run shock in GDP, inflation, and bank size will give rise to a long-term relationship with Islamic bank financing. Therefore, the results support Hypothesis 2. Moreover, the impulse response function indicated that Islamic bank financing got stable during the financial crisis. The dynamic responses are stable despite the economic cycle volatility in these countries. This enables Islamic banks to cushion economic instability, attract more customers, and provide more funds.

Operating under complicated circumstances, Islamic banks are not immune from the economic and political conditions in the Middle Eastern countries. Therefore, it seems exposed to some systematic risks such as price level shock and inflation, which needs to be accounted for by Islamic banking sector credit management. Finally, this article suggests further research directed in the dynamic response of Islamic bank financing during the 2020 COVID-19 pandemic crisis.

\section{AUTHOR CONTRIBUTIONS}

Conceptualization: Mohammed Abusharbeh.

Data curation: Mohammed Abusharbeh.

Formal analysis: Mohammed Abusharbeh.

Funding acquisition: Mohammed Abusharbeh.

Investigation: Mohammed Abusharbeh.

Methodology: Mohammed Abusharbeh.

Project administration: Mohammed Abusharbeh.

Resources: Mohammed Abusharbeh.

Software: Mohammed Abusharbeh.

Supervision: Mohammed Abusharbeh.

Validation: Mohammed Abusharbeh.

Visualization: Mohammed Abusharbeh.

Writing - original draft: Mohammed Abusharbeh.

Writing - review \& editing: Mohammed Abusharbeh.

\section{REFERENCES}

1. Abdul Kader, R., \& Leong, Y. (2009). The impact of interest rate changes on Islamic bank financing. International Review of Business Research Papers, 5(3), 189-201. Retrieved from https:// www.researchgate.net/publication/253773592_The_Impact_of_ Interest_Rate_Changes_on_Islamic_Bank_Financing

2. Adebola, Solarin Sakiru, Wan Sulaiman, Wan Yusoff, \& Jauhari, Dahalan. (2011). The impact of macroeconomic variables on Islamic banks financing in Malaysia. Research Journal of Finance and Accounting, 2, 22-32. Retrieved from https://www.researchgate. net/publication/286446370_ The_impact_of_macroeconomic_variables_on_Islamic_ banks_financing_in_Malaysia

3. Bakri, Abdul Karim, Zulkefly, Abdul Karim, \& Shukri, M. (2017). Determinants of Islamic bank financing in Malaysia: An empirical study using linear and nonlinear ARDL model. Jurnal Ekonomi Malaysia,
51, 15-22. Retrieved from https://www.researchgate.net/ publication/323589192_Determinants_of_islamic_bank_ financing_in_Malaysia_An_empirical_study_using_linear_and_ nonlinear_ARDL_model

4. Chakroun, M., \& Gallali, M. (2015). Islamic banks and financial stability: An empirical analysis of the Gulf countries. International Journal of Business and Commerce, 5(3), 64-87. Retrieved from https://www.ijbcnet.com/5-3/IJBC-15-5212.pdf 
5. Cham, T. (2018). Determinants of Islamic banking growth: an empirical analysis. International Journal of Islamic and Middle Eastern Finance and Management, 11(1), 18-39. https://doi.org/10.1108/IMEFM-01-2017-0023

6. Čihak, M., \& Hesse, H. (2010) Islamic banks and financial stability: An empirical analysis. Journal of Financial Services Research, 38(2-3), 95-113. https:// doi.org/10.1007/s10693-0100089-0

7. Dickey, D. A., \& Fuller, W. A. (1981). Likelihood ratio statistics for autoregressive time series with a unit root. Econometrica, Journal of the Econometric Society, 49, 5772. Retrieved from https://www. jstor.org/stable/1912517?seq=1

8. Ellahi, N., Bukhari, T., \& Naeem, M. (2010). Role of Islamic modes of financing for growth of SMEs A case study of Islamabad city. International Journal of Academic Research, 2(6), 161-171. Retrieved from https://www.researchgate. net/publication/255966913_Role_ of_Islamic_Modes_of_Financing_for_GrowthOf_Smes_a_Case_ Study_of_Islamabad_City

9. $\quad$ Enders, W. (1995). Applied econometric time series. New York: John Wiley \& Sons, Inc.

10. Granger, C. W. J. (1969). Investigating causal relations by econometric models and crossspectral methods. Econometrica: Journal of the Econometric Society, 37, 24-36. Retrieved from https://www.jstor.org/ stable $/ 1912791$ ? seq $=1$

11. Granger, C. W., \& Yoon, G. (2002) Hidden co-integration (Working Paper 2002-02). University of California. http://dx.doi. org/10.2139/ssrn.313831

12. Granger, C. W. J., \& Engle, R. F. (1987). Co-integration and error correction: representation, estimation and testing. Econometrica, 55(2), 251-276. Retrieved from https://www.jstor. org $/$ stable $/ 1913236$ ? seq $=1$

13. Gujarati. (2004). Basics econometrics (4th ed.) New York: McGraw Hill.
14. Hanif, M., \& Iqbal, A. (2010). Islamic financing and business framework: A survey. European Journal of Social Sciences, 15(4), 475-489. Retrieved from https://core.ac.uk/download/ pdf/10632282.pdf

15. Haron, S. (2004). Determinants of Islamic bank profitability. Global Journal of Finance and Economics, 1(1). 2-18. Retrieved from https:// ie.um.ac.ir/images/329/Articles/ Others/Latin/Determinants $\% 20$ of $\% 20$ Islamic\%20Bank\%20Profitability.pdf2.pdf

16. Hasan, M., \& Dridi, J. (2010). The effects of the global crisis on Islamic and conventional banks: $a$ comparative study (IMF Working Paper, WP/10/201). International Monetary Fund, Washington. Retrieved from https://ssrn.com/ abstract $=1750689$

17. Ibrahim, M., \& Sufian, F. (2014). A structural VAR analysis of Islamic financing in Malaysia. Studies in Economics and Finance, 31(4), 371-386. https://doi.org/10.1108/ SEF-05-2012-0060

18. International Islamic Finance Board. (2019). Aggregated structural Islamic financial indicators (official publication). Retrieved from https://www.ifsb. org/psifi_05.php

19. Johansen, S. (1988). Statistical analysis of co-integration vectors. Journal of Economic Dynamics and Control, 12(2-3), 231-254. https://doi.org/10.1016/01651889(88)90041-3

20. Kasri, Rahmatina. (2010). The determinants of Islamic banking growth in Indonesia. http://dx.doi. org/10.2139/ssrn. 1740500

21. Kassim, S. (2016). Islamic finance and economic growth: The Malaysian experience. Global Finance Journal, 30, 66-76. https:// doi.org/10.1016/j.gfj.2015.11.007

22. Moghul, U., \& Ahmed, A. (2003). Contractual forms in Islamic finance law and Islamic Inv. Co. of the Gulf (Bahamas) Ltd. v. Symphony Gems N.V. \& Ors.: a first impression of Islamic finance. Fordham International Law Journal, 27(1). New York:
Fordham University School of Law. Retrieved from https:// www.researchgate.net/publication/254597957_Contractual_ Forms_in_Islamic_Finance_Law_ and_Islamic_Inv_Co_of_the_ Gulf_Bahamas_Ltd_v_Symphony_ Gems_NV_Ors_A_First_Impression_of_Islamic_Finance

23. Mushtaq, S., \& Siddiqui, A. (2017). Effect of interest rate on bank deposits: evidences from Islamic and non-Islamic economies. Future Business Journal, 3, 1-8. https://doi.org/10.1016/j. fbj.2017.01.002

24. Naha, S., \& Sarker, N. (2016). Are macroeconomic factors substantially influential for Islamic bank financing? Cross-country evidence. Journal of Business and Management, 18(6), 20-27.

25. Nawaz, H. (2019). An investigation into factors that determine the growth rate in the Islamic banking and finance. Future Business Journal, 5(1). https://doi.org/10.1186/s43093019-0003-7

26. Nursyamsiah, T. (2017). Macroeconomic determinants of Islamic banking financing. Tazkia Islamic Finance and Business Review, 11, 145-164. Retrieved from https://www.neliti.com/publications/271347/macroeconomicdeterminants-of-islamic-bankingfinancing

27. Pesaran, M. H., Shin, Y., \& Smith, R. J. (2001). Bounds testing approaches to the analysis of level relationships. Journal of Applied Econometrics, 16(3), 289-326. https://doi.org/10.1002/jae.616

28. Phillips, P., \& Perron, P. (1988). Testing for a unit Root in time series regression. Biometrika, 75(2), 335-346. https://doi. org/10.1093/biomet/75.2.335

29. Quan, L., Ramasamy, S., Rasiah, D., Yee Yen, Y., \& Devi Pillay, S. (2019). Determinants of Islamic banking performance: An empirical study in Malaysia (2006-2016). Humanities and Social Sciences Reviews, 7(6), 380-401. https://doi.org/10.18510/ hssr.2019.7664 
30. Rajhi, W., \& Hassairi, S. (2013). Islamic banks and financial stability: A comparative empirical analysis between MENA and Southeast Asian countries. Région et Développement, 37, 150-177. Retrieved from https://www.researchgate.net/ publication/275843596_Islamic_Banks_and_Financial_ Stability_A_Comparative_Empirical_Analysis_between_MENA_ and_Southeast_Asian_Countries

31. Sakarya, B. (2016). Financial stability of Islamic (participation) banks in Turkey (MPRA Paper, ID; 69451). Turkey. Retrieved from https://mpra.ub.uni-muenchen. de/69451/1/MPRA_paper_69451. pdf
32. Selim, M. (2020). Financing homes by employing Ijara based diminishing Musharaka. International Journal of Islamic and Middle Eastern Finance and Management, 13(5), 787-802. https://doi.org/10.1108/IMEFM-05-2019-0217

33. Setyowati, N. (2019).

Macroeconomic determinants of Islamic banking products in Indonesia. Economies, 57(7), 1-15. https://doi.org/10.3390/economies 7020053

34. Shahid, M. A., \& Abbas, Z. (2012). Financial stability of Islamic banking in Pakistan: An empirical study. Journal of Business Management, 6(10), 3706-3714. Retrieved from http://www.aca- demicjournals.org/app/webroot/article/article1380874968_Shahid\%20 and\%20Abbas.pdf

35. Shaikh, A. (2014). Determinants of Islamic banking growth in Pakistan. http://dx.doi.org/10.2139/ ssrn. 2398425

36. Tariq, A., \& Masih, M. (2016). Risksharing deposits in Islamic banks: Do interest rates have any influence on them? (MPRA paper, no. 71680). Retrieved from https://mpra. ub.uni-muenchen.de/71680

37. Zahid, S., \& Basit, A. (2018). Impact of macroeconomic factors on the growth of Islamic banking: A case of Pakistan. Journal of Finance \& Economics Research, 3(2), 37 50. http://dx.doi.org/10.2139/ ssrn.3146727 